\title{
THE REACTION OF DENTAL PULP TO ESCHERICHIA COLI LIPOPOLYSACCHARIDE AND ENTEROCOCCUS FAECALIS LIPOTEICHOIC ACID
}

\author{
Laudimar Alves de Oliveira*; Sérgio Valmor Barbosa
}

\begin{abstract}
DDS, Universidade de Brasília, Faculdade de Ciências da Saúde, Departamento de Odontologia, Laboratório de Biomateriais, Brasília, DF, Brasil
\end{abstract}

Submitted: September 09, 2002; Returned to authors for corrections: January 07, 2003; Approved: April 07, 2003

\begin{abstract}
This research evaluates the effects of the lipopolysaccharides (LPS) from Escherichia coli and lipoteichoic acid (LTA) from Enterococcus faecalis on dental pulp. These molecules are components of the Gramnegative and Gram-positive bacteria cell wall, respectively. Ten dogs were used in the experiment. Inoculation in surgically opened pulp and coronal restoration with glass ionomer was the method chosen. The evaluation times were 1, 7, 15, 30 and 60 days. The results showed that the LPS and LTA, at $150 \mu \mathrm{g} /$ $\mathrm{ml}$, produced a negative interference in the pulp leading to destruction. LTA caused less damage than LPS.
\end{abstract}

Key words: lipopolysaccharide, endotoxin, lipoteichoic acid, dental pulp, bacteria

Lipoteichoic acid (LTA) and lipopolysaccharides (LPS) are components of the bacterial cell wall that can induce pulp inflammation and periapical infections, including lethal cellular aggression (9). The lipid portion of the cellular membrane associated with teichoic acids from the cell wall form lipoteichoic acids which are encountered solely in Gram positive bacteria (8). Lipopolysaccharide can be identified as a lipid complex called lipid A, bound to a polysaccharide present in the outer membrane of Gram-negative bacteria. This endotoxin was associated with repeated sepsis and inhibition of DNA production, diminishing protein synthesis (3).

This experiment assessed the inflammatory response in the dental pulp of dogs to Escherichia coli lipopolysaccharide and Enterococcus faecalis lipoteichoic acid, at $150 \mu \mathrm{g} / \mathrm{ml}$ concentration.

Ten three-year-old healthy male dogs were selected. They received food and water ad libitum. The dogs were submitted to anesthesia with Rompum (Bayer do Brasil) and Thionembutal, e.v. (Abbott Laboratorios do Brasil) and the surgical field was isolated with a rubber dam leaving only the experimental teeth exposed. Prophylaxis of the teeth was performed with a water- refrigerated rubber point. Antisepsis was carried out using a $2 \%$ iodide alcohol.

A low-speed, water refrigerated \#2 diamond bur was used on the bucal surface to obtain access to the pulp. Access was considered to be achieved upon bleeding. Once opened, the cavity was washed with saline solution and then dried with a cotton pellet. After inoculation with $0.05 \mathrm{ml}$ of test material, cavities were sealed with glass ionomer cement (Vidrion R - SS White - Rio de Janeiro - RJ). After the intervention, animals were confined with food and water ad libitum.

LPS was obtained from Escherichia coli Serotype 055.B5, L-4524. Lot 11H4085, and LTA from Enterococcus faecalis, L4015 - Lot. 104H4039 and Lot 11344013 (Sigma Laboratory - USA) $(150 \mathrm{mg} / \mathrm{ml})$. Four teeth from each animal were used. Group I (control group) consisted of unprepared canines (i.e., only healthy pulp). The third right pre-molars, which were prepared with surgical access and ionomer restoration, formed Group II. The $4^{\text {th }}$ right pre-molars, which were prepared with access, LPS and ionomer restoration, formed Group III. The $4^{\text {th }}$ left pre-molars, which were prepared with access, LTA and ionomer restoration, formed Group IV. Evaluation times were 1, 7, 15,30 and 60 days.

\footnotetext{
* Corresponding author. Mailing address: SQS 210, Bloco K, Apto 408. 70273-110, Brasília, DF, Brasil. Telephone: (+5561) 2429506, (+5561)
} 99646119. Fax: (+5561) 307 3714. E-mail: lauodonto@uol.com.br 
In each period, two dogs were killed by Thionembutal, e.v. (Abbott Laboratorios do Brasil) overdosage. Samples were obtained by bone resection. Pieces were washed and decalcified with nitric acid at 5\%. The histological preparation was undertaken concluding with hematoxylin and eosin staining. The staining technique described by Brown and Brenn (1) was used to detect the presence of any bacterial strain in pulp tissue during experimentation.

The results showed that LPS and LTA enhanced inflammation in the dental pulp of dogs. The inflammatory response was high with an increase in leukocyte population. The tissue structure was irregular presenting some necrosis areas.

Group I (healthy pulp) displayed connective tissue characterized by normal cells and regular organization. Group II (with surgical trauma) showed a limited damage identified by fibrosis and coagulation. The tissue structure presented tecidual reorganization.

In LPS samples (Group III) significantly high mononuclear infiltration was observed between hemorrhage points, more evident on the thirtieth and sixtieth days. The tissue disorganization with necrosis areas was due to inflammation (Fig. 1).

In the present study, the beginning of the reaction was similar to the trauma caused by mere access to the pulp (control group). After 7 days, there was a modification, signalled by an increase in polymorphonuclear cells and inflammatory edema. The edema associated with the particular location, entirely enclosed in a mineralized tissue, the dentin, caused metabolic collapses with vascular stasis. At 15 days, the breakdown of the pulp matrix was more evident. The effect after 30 days was the enhancement of

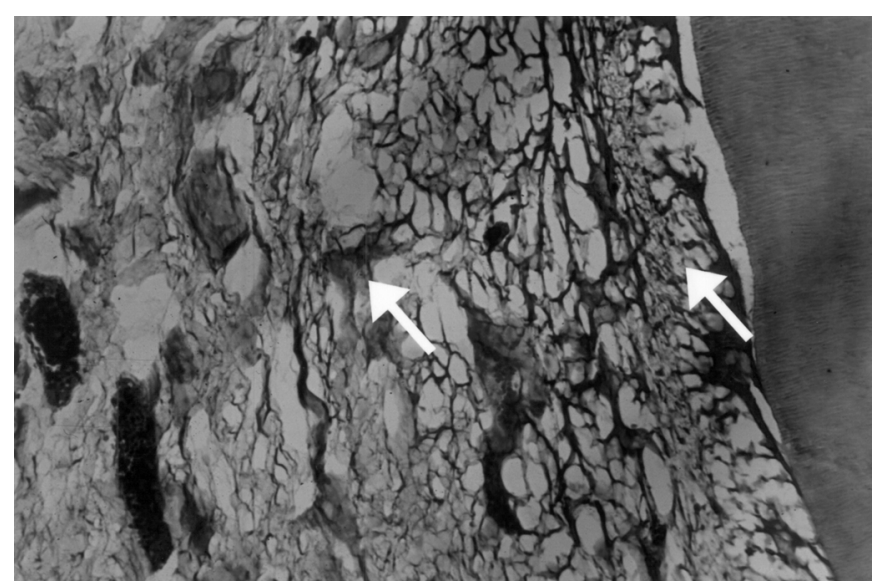

Figure 1. Photomicrograph of pulp inoculated by $150 \mu \mathrm{g} / \mathrm{ml} E$. coli LPS at 60 days showing complete breakdown of pulp matrix with necrosis areas - arrows. (HE; $400 \mathrm{X}$ ). inflammation with increased presence of mononuclear leukocytes and necrosis areas. At 60 days the tissue was irregular with necrosis and hemorrhage points.

The inflammatory effects of endotoxin are numerous. LPS induces prostaglandins, leukotrienes, PAF, complement $3 \mathrm{a}$ and 5a, and interleukin-1 (3). Cell growth inhibition has been related to endotoxin. Nakane et al. (7) have shown that the relation is time and dose dependent. Such inhibition was observed in the present experiment. The destructive capacity of these molecules was likewise observed.

In LTA samples (Group IV) less enhanced inflammatory tissue was observed than in the LPS group. It was initially similar to LPS with ingurgitated vessels, but at the thirtieth and sixtieth days LTA showed high mononuclear infiltration with few necrosis areas. In this study endotoxin proved to be more aggressive than LTA with great destruction of pulp tissue and several instances of necrosis. The increase of mononuclear leukocyte stimulation has also been observed by Keller $\mathrm{et}$ al. (5) in analysis of macrophage response to lipoteichoic acids. The tissue structure was irregular with hemorrhage points (Fig. 2).

Sugiyama et al. (8) have shown that LTA from various Grampositive bacteria enhance the production of hepatocyte growth factor (HGF) by human gingival fibroblasts in culture. The control of these substances is an important step toward solving general infections.

Pharmacological substances for eliminating LPS and LTA have been studied. Buck et al. (2) have observed LPS deactivation by irrigation substances.

This study demonstrated that, $150 \mu \mathrm{g} / \mathrm{ml}$, LPS and LTA affect pulp, leading to destruction of the pulp tissue. Less damage was caused by LTA than by LPS.

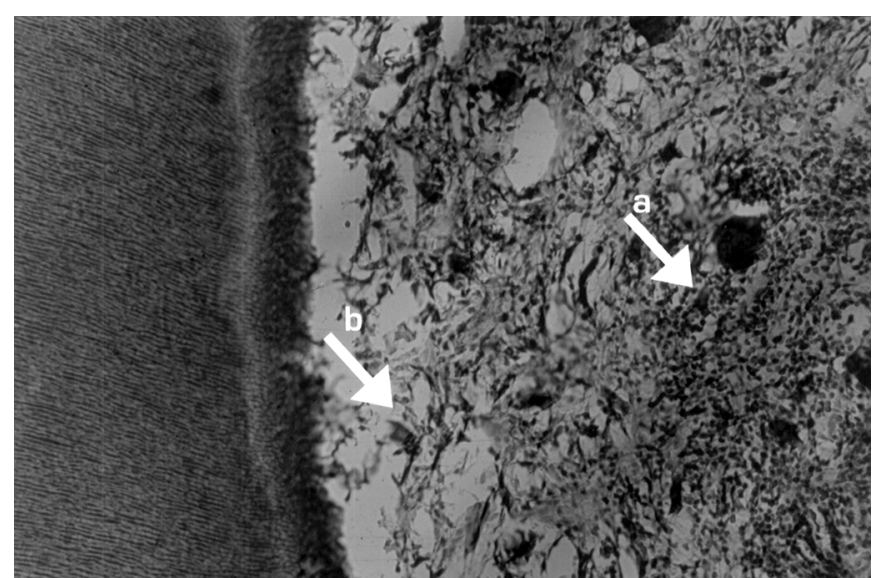

Figure 2. Photomicrograph of pulp tissue inoculated by 150 $\mu \mathrm{g} / \mathrm{ml}$ S. faecalis LTA at 60 days showing high mononuclear infiltration (a) with necrosis areas (b) - arrows.(HE; $400 \mathrm{X}$ ). 


\section{RESUMO}

\section{Reação da polpa dental ao lipopolissacarídeo de Escherichia coli e ao ácido lipoteicóico de Enterococcus faecalis}

O presente trabalho avaliou os efeitos do ácido lipoteicóico (LTA) e do lipopolissacarídeo (LPS) no tecido pulpar. Essas moléculas estão presentes nas paredes das bactérias Grampositivas e Gram-negativas, respectivamente. Utilizaram-se dez cães para inoculação das substâncias em polpas expostas cirurgicamente. Os períodos de avaliação foram de 1, 7, 15,30 e 60 dias. Os resultados demonstraram que $150 \mu \mathrm{g} / \mathrm{ml}$ de LPS e LTA interferem negativamente na polpa promovendo destruição tecidual. O LTA estabeleceu um padrão citotóxico menos agressivo que o LPS.

Palavras-chave: lipopolissacarídeo, endotoxina, ácido lipoteicóico, polpa dental, bactéria

\section{REFERENCES}

1. Brown, J.H.; Brenn, L. A method for the differential staining of Gram positive and Gram negative bacteria in tissue sections. Bulletin of the John Hopkins, vol. XLVIII, n. 2, p. 69-73, 1931.
2. Buck, R.A.; Cai, J.; Eleazer, P.D.; Staat, R.H.; Hurst, H.E. Detoxification of endotoxin by endodontic irrigants and calcium hydroxide. J. Endod., v. 27, n. 5, p. 325-327, May. 2001.

3. Chow, J.C.; Young, D.W.; Golenbock, D.T.; Christ, W.J.; Gusovsky, F. Toll-like receptor-4 mediates lipopolysaccharide-induced signal transduction. J. Biol. Chem., v. 16, n. 4, p. 10689-10692, April. 1999.

4. Hosoya, S.; Matsushima, K. Stimulation of interleukin-12 production of human dental pulp cells by Porphyromonas endodontalis lipopolysaccharide. J. Endod., v. 23, n. 1, p. 39-42, Jan. 1997.

5. Keller, R.; Fischer, W.; Keieist, R.; Bassetti, S. Macrophage response to bacteria:Induction of marked secretory and cellular activities by lipoteichoic acids. Infect. Immun., 60(9): 3664-72, 1992.

6. Nakane, A.; Yoshida, T.; Nakata, K.; Horiba, N.; Nakamura, H. Effects of lipopolysaccharides on human dental pulp cells. J. Endod., v. 21, n. 3, p. 128-130, Mar. 1995.

7. Schonfeld, S.E.; Greening, A.B.; Glick, D.H.; Frank, A.L.; Simon, J. H.; Herles, S.M. Endotoxic activity in periapical lesions. Oral Surg., v. 53, n. 1, p. 82-87, Jan. 1982.

8. Sugiyama, A.; Arakaki, R.; Ohnishi, T.; Arakaki, N.; Daikuhara, Y.; Takada, H. Lipoteichoic acid and interleukin 1 stimulate synergistically production of hepatocyte growth factor (scatter factor) in human gingival fibroblasts in culture. Infect. Immun., v. 64, n. 4, p. 1426-1431, Apr. 1996.

9. Warfvinge, J.; Dahlén, G.; Bergenholtz, G. Dental pulp response to bactéria cell wall material. J. Dent. Res., 64(8): 1046-50, Aug. 1985. 